\title{
PAEDIATRICS IN THERESIENSTADT GHETTO
}

\author{
Kateřina Horáčková1, 2, Andrea Ševčovičová3 ${ }^{3}$ Zdenek Hrstka', Jana Wichsová1, Monika Zaviš \\ ${ }^{1}$ Faculty of Health Studies, University of Pardubice, Pardubice, Czech Republic \\ ${ }^{2}$ Faculty of Military Health Sciences, University of Defence, Hradec Králové, Czech Republic \\ ${ }^{3}$ St. Elizabeth University of Health and Social Work, Bratislava, Slovak Republic \\ ${ }^{4}$ Faculty of Education, Comenius University, Bratislava, Slovak Republic
}

\begin{abstract}
SUMMARY
The main objective of this study is to describe the most common childhood diseases occurring in the Theresienstadt ghetto during the Second World War as well as applied anti-epidemic measures. A partial objective is to describe medical and nursing care of sick child prisoners. The data was obtained by the method of synthesis of primary and secondary data with the highest importance after adequate external source criticism using selected monographs, memoirs, survivor diaries, Orders of the day by the Council of the Elders and Reports of the Jewish self-government of the Theresienstadt ghetto from 1941 to 1945, the Archives of the Jewish Museum in Prague, the Ghetto Museum, the Museum of the History of Polish Jews in Warsaw, Post Bellum online electronic collection of oral historical interviews, and witness accounts. The validity of the presented conclusions is ensured by comparing data from several sources.

The most common infections in Theresienstadt children were enteritis, scarlet fever, infectious jaundice, measles, mumps, rubella, varicella, black cough, pneumonia, otitis media, and typhoid fever. Most of these infections had entirely atypical symptomatology or complications. Children were hospitalized in children's hospitals, in children's rooms of hospitals for adults and infirmaries in children's homes. Albeit diagnostic methods had a high standard, options of treatment were very limited. The most common treatments included bed rest, diet and cold compress. Occasionally, chemotherapeutic agents (e.g. a sulphonamide drug Prontosil) and Aspirin were available. The anti-epidemic measures in the ghetto focused on hygiene, enhancing children's immunity, vaccination and pest control.
\end{abstract}

Key words: Theresienstadt, children, infectious diseases, anti-epidemic measures

Address for correspondence: K. Horáčková, Faculty of Health Studies, University of Pardubice, Průmyslová 395, 53210 Pardubice, Czech Republic. E-mail: katerina.horackova@upce.cz

https://doi.org/10.21101/cejph.a5557

\section{INTRODUCTION}

"There were 15,000 of them, but only 100 returned." (1)

The period of Holocaust in the territory of former Czechoslovakia is most often associated with Theresienstadt (or "the garrison city of Theresienstadt") which became a part of Nazi plans for a new European arrangement, the so-called "final solution to the Jewish question", during the Second World War. Theresienstadt was one of 10,000 camps, those frightening symbols of Nazi Germany and Genocide. Jews from Bohemia, Germany, Austria, the Netherlands, Denmark, France, and, at the end of the war, also from Hungary and Slovakia were deported to Theresienstadt ghetto. The camp served predominantly as a gathering point for Jews and as a transit camp before they were sent to extermination or labour concentration camps in the "Reichskommissariat Ostland" or the General Government as Reich territory. Between 24 November 1941 and 9 May 1945, 139,654 prisoners were deported to Theresienstadt, 207 prisoners were born in the ghetto. The criteria determining the fate of a Jewish prisoner from Protectorate Bohemia and Moravia were clearly defined by the Nuremberg Laws; the age of the potential prisoner was of no significance. There was an exception in case of "Mischlinge" or "mixed-breed" who were taken from their families at the age of 14 and sent to Theresienstadt on their own. Children started to arrive in Theresienstadt with the first transports from Brno and Prague in December 1941 and, together with the elderly, were the most vulnerable group of the prisoners. Despite all sympathy, a considerable interest and care from other prisoners and the so called "Jewish self-government" of Theresienstadt, the forced stay in Theresienstadt was a significant change of environment associated with psychological, physical, social, spiritual, educational, and cultural damage for the children (2-5). According the memories of children ex-prisoners, Theresienstadt was a place of true friendship, where they get many useful skills, where they were educated and get a relationship to sport or art. Even today, 75 years after the war, they like to remember the humorous experiences of this place.

Children were the same prisoners as their parents, and they were subjected to the same camp regime. At the beginning, children were accommodated in closed barracks only. Children under the age of 12 were accommodated with their parents (girls with their mothers, boys with fathers). Later, this regulation was changed, and only children under 4 years of age could stay with their parents. From the summer of 1942, there were fewer restrictions and the children were allowed to barracks court, and even 
to the streets of the camp. During this period, children from 4 to 10 years of age stayed in "children's homes", children from 10 to 16 old stayed in "boys' homes" and "girls' homes", and the youth (from 16 to 20 years) lived in "apprentices' homes" or "homes for young workers". Care for children and for the youth was not seen merely as a responsibility of the camp self-government, but it was primarily a mission to preserve and support the next generation $(1,6)$.

Although the field of pedagogical and educational activities for children in Theresienstadt has been sufficiently researched, the research of the field of health care has been hitherto neglected. Therefore, the research of care for child prisoners should be complemented by the study of health care in relation to living, hygienic, and catering conditions, and also in relation to psychological aspects of forced internment. Naturally, there would be a certain overlap between these two fields, especially in the area of prevention $(1,6)$. The objective of the study was to describe the most common children's diseases, and also relevant anti-epidemic measures, as well as to describe medical and nursing care for child prisoners in the Theresienstadt ghetto.

\section{MATERIALS AND METHODS}

The following historical overview is created by the method of synthesis of primary and secondary data with the highest importance after adequate external criticism of the source (investigation of the authenticity of the source, the time and place of origin, the author, the situation of origin, the time gap between the event itself and the recording of the event - deliberate and unintentional mistakes, counterfeits or later additions). Selected monographs, memoirs, survivor diaries, Orders of the day by the Council of the Elders and Reports of the Jewish selfgovernment of Theresienstadt from 1941 to 1945, the Archives of the Jewish Museum in Prague, the Ghetto Museum, the Museum of the History of Polish Jews in Warsaw, Post Bellum online electronic collection of oral historical interviews, and witness accounts were selected for assessment. The validity of the presented conclusions is ensured by comparing data from several sources.
The created text has been complemented noticeably by data from Theresienstadt ghetto survivors. The witnesses were addressed through Czech Jewish periodicals (Theresienstadt Initiative) by a repeated announcement in which the author tried to address the survivors with a personal experience of being a patient either in the Theresienstadt hospital or infirmary. Two readers responded to the challenge and both met the criteria of the research. Thus two children from Theresienstadt contributed their memories to the following text - Michaela Vidláková (born December 12th 1936, living in Prague, the Czech Republic, who fell ill with diarrhoeal disease, scarlet fever, measles, and typhoid fever in Theresienstadt) and Marta Kottová (born February 24th 1929 - deceased 2017, who fell ill with typhoid fever, scarlet fever, leptospirosis, and encephalitis). From the ethical point of view, the essential condition for this research activity was that the interview should not endanger the physical or mental health of witnesses. Also, both women had the opportunity to comment on the text concerning their persons and signed informed consent and agreed with the publication of their names.

\section{RESULTS}

The main factors leading to weakening of the children's organisms were the living conditions of the ghetto. A major problem throughout the existence of the ghetto was overpopulation* (Table 1 shows the number of children aged $0-15$ years in the reference period), although there was a significant drain of children caused by frequent transports (Table 2 shows numbers of children aged 0-15 years deported from Theresienstadt as of 12th October 1944). Both tables were created based on statistical data from Prochnik (7) and completed by data from Lederer (8).

The above-mentioned living conditions included the lack of accommodation, food and hygienic conditions, and cold. All of this led to the emergence of illnesses that often reached epidemic proportions and, in some cases, proved fatal.

The most common childhood diseases in Theresienstadt were of infectious origin. The number of cases of the most common infectious diseases in Theresienstadt is shown in Table 3. In particular, these diseases included encephalitis and meningitis (the

Table 1. Number of children in Theresienstadt during the course of its existence

\begin{tabular}{|l|c|c|c|c|c|}
\hline & Males $\mathbf{0 - 1 5}$ & Males totally & Females 0-15 & Females totally & Children 0-15 \\
\hline July 1942 & 1,376 & 16,915 & 1,311 & 26,468 & 2,687 \\
\hline December 1942 & 1,787 & 20,012 & 1,708 & 29,284 & 3,495 \\
\hline July 1943 & $\mathrm{n} / \mathrm{a}$ & 19,000 & $\mathrm{n} / \mathrm{a}$ & 27,125 & $\mathrm{n} / \mathrm{a}$ \\
\hline December 1943 & 1,586 & 14,200 & 1,445 & 20,455 & 3,031 \\
\hline May 1944 & 1,430 & 12,070 & 1,302 & 15,907 & 2,732 \\
\hline December 1944 & 378 & 3,268 & 441 & 7,809 & 819 \\
\hline April 1945 & 815 & 6,839 & 796 & 10,676 & 1,611 \\
\hline May 1945 & 1,083 & 12,630 & 1,065 & 17,296 & 2,148 \\
\hline
\end{tabular}

*According to the census of 1930, 7,181 citizens lived in 219 houses on an area of 411 ha in Theresienstadt. In July 1942, there were 21,000 inhabitants and in September 1942 about 57,000. This period was called overpopulation. We can see the highest number of children, infection diseases and anti-epidemic measures during this period. The numbers were falling since autumn 1943 when the child transports to concentration camps began (2). 
Table 2. Numbers of children deported from Theresienstadt as of 12th October 1944, aged 0-14, by gender

\begin{tabular}{|l|c|c|c|}
\hline & Girls 0-14 & Boys 0-14 & Total \\
\hline 1942 & 1,049 & 1,045 & 2,094 \\
\hline 1943 & 628 & 669 & 1,297 \\
\hline 1944 & 760 & 855 & 1,615 \\
\hline Total & 2,437 & 2,569 & 5,006 \\
\hline
\end{tabular}

Source: Prochnik (7), Lederer (8)

most common causes of death in children), scarlet fever, enteritis, infectious jaundice, measles, mumps, rubella, varicella, pertussis, pneumonia, otitis media, typhoid fever, and other intestinal infections $(1,8)$. The authors of the Theresienstadt statistics report only numbers of all the cases without age stratification.

Scarlet fever occurred already at the beginning of the camp. The total number of patients infected with this disease was 1,857 according to Prochnik (7) and Lederer (8). The epidemic was the worst in time of overcrowded of ghetto - between July 1942 and the end of the same year. Adler (6) refers that total number of sick people with this ill was 896 in the second part of 1942 . The cause was frequent transports of children and adolescents. The course of the disease was often complicated by measles, otitis, diphtheria, and myocarditis. There were also cases of a milder course of the disease, when the first symptom was a peeling skin. Patients with this disease were treated in the so-called "scarlet fever hospital", which was located in the building Q217/19, where MUDr. Hans Schaffa (transported to Theresienstadt on 22 May 1942, transported to Auschwitz by Transport En on 4th October 1944 where he died) was a head doctor. Children with other infections (e.g. typhoid fever or furunculosis) were placed here as well (6-8).

Enteritis was one of the most common infectious diseases. Adler (6) estimates the total number of patients affected by this infection as 50-60,000 for the total time of the camp's existence and for all ages**.

Adler (6) estimates the number of cases of infectious jaundice at 2,000. Contaminated food was probably transducer of the infection. The disease often occurred in its chronic form without typical yellowing. Jaundice was treated by bed rest and administration of sugar (per os or intravenously). In her memories of her life in Theresienstadt, Helga Pollaková reports the first case of this disease in her girlfriend Judith Schwarzbartová, who subsequently caused an epidemic (9).

A total of 1,129 of prisoners suffered from measles at the time of the camp's existence. Mostly children of pre-school age, the course of disease was serious, and the convalescence was long $(1,6,7)$

Mumps were common, especially in the fall of 1942. The total number of cases in the camp was 978. It can be assumed that most of these cases were in children and youth. The course of the disease was lengthy, serious, often complicated by acute scrotum and swelling of the glands $(1,6)$.

Rubella spread especially in 1942. Both children and adults were infected, but the course of the disease was mild. This was also true for the course of varicella, pertussis and otitis media, which occurred mainly in children $(1,6)$.

To the occurrence of tuberculosis significantly contributed overcrowded accommodation, reduction of immunity, and damp and cold environment. Prochnik and Lederer $(7,8)$ report an approximate number of all cases of tuberculosis in all prisoners as 2,100 (of which were 7 children under the age of 14 and 12 persons aged 15-24). Karel Löwith (10) reports similar figures in his statistics. The onset of the disease often occurred after lung and pleura inflammation. In addition to lungs, other organs were also affected, most often the intestines. In children and adolescents there were cases of both mild and serious, fatal form. There was a great effort to heal children, and it was surprising that some of the diseases were cured even under such difficult conditions of the camp and without antibiotics. In addition to physical interventions (especially stay in the fresh air), the main therapeutic principle was bed rest in the "Tuberculosis department" in building E III a. Patients with tuberculosis received small food supplements. In May 1944, before the expected Red Cross inspection, all the inmates of the tuberculosis department were deported to Auschwitz $(1,6,9)$.

The poliomyelitis epidemic occurred in Theresienstadt for the first time as late as at the end of the summer of 1943. The most affected were the youth aged between 15 and 20 years $(1,6)$.

Encephalitis did not occur until 1943, usually as a result of poliomyelitis according to Prochnik and Lederer $(7,8)$. The total number of cases was 1,000 . Often the course of this disease was light, without complications. Typical symptoms included fever,

Table 3. Numbers of most frequently occurring children's diseases in Theresienstadt

\begin{tabular}{|l|c|c|c|c|}
\hline Infectious disease & 1942 & 1943 & 1944 & Total \\
\hline Measles & 891 & $236(8$ fatal $)$ & 2 & 1,129 \\
\hline Pertussis & 282 & $110(1$ fatal $)$ & 13 & 405 \\
\hline Mumps & 587 & 366 & 25 & 978 \\
\hline Rubella & 110 & 92 & 172 & 261 \\
\hline Varicella & 226 & 448 & 846 \\
\hline
\end{tabular}

Source: Lagus, Polák (1), Prochnik (7), Lederer (8)

\footnotetext{
**Prisoners even called it "Theresienstadt disease", and contaminated drinking water was considered as the main cause. The water taps were in a technically bad shape (rusted pipes, insufficient pressure of water), which often lead to the fact that water from the Ohře river got into drinking water. Adler $(2,6)$ mentions very toxic forms (50 stools a day) in children and the youth, when recovery was often not possible. Cleansing enemas, sulphonamides (Albucid), sugar therapy (the children were deprived of food for 2 to 3 days, and 400-500 g of sugar were administered daily) were used for treatment. Due to poor hygienic conditions, and overall weakening of immunity, the occurrence of pressure ulcers in children was noted (6).
} 
headache, balance disturbances, or increased drowsiness. Symptoms changed very quickly, and it required a long-term treatment. The disease affected predominantly younger women. Helga Weiss mentions this disease in her diary.

"The jaundice and typhoid came out of fashion. There was a new disease again, encephalitis. The entire typhoid department in the former gym of Sokol gymnastic society was cleared for patients of encephalitis. The most cases are as always in building $L$ 410. We were quarantined for a few days. Apart from a few more serious cases, the disease has an easy course. "In her diary she further describes a so-called "encephalic head", which involved forgetting things and extreme fatigue (9).

Diphtheria was reported in Theresienstadt in 1,100 cases, of which 38 were fatal. The course of the disease was usually mild, rarely leading to soft palate paresis or heart damage, PlautVincent's angina was common $(1,6,9)$. Children often contracted impetigo, which spread very quickly from child to child. The course of the disease was protracted, and it healed poorly (6).

Paediatrics in the Theresienstadt ghetto did not deal with infectious diseases only. The natural psychomotor development of children was degraded, and many children suffered from mental illnesses. These children were hospitalized at a clinic run by Gertruda Bäumlová (deported to Theresienstadt on July 2, 1942 by transport AA1, deported to Auschwitz by the transport of Et on 23 October 1944, murdered in Auschwitz) (11). She was assisted by her husband, psychoanalyst Frantisek Bäuml (deported to Theresienstadt on July 2, 1942 by transport AA1, deported to Auschwitz by transport Ek on September 28, 1944, also murdered in Auschwitz) (11). The most critical patients were kept at the clinic, and neurotic children who had experienced severe psychological trauma returned to the care of wardens in children's homes after a medical treatment. Another big problem not only among children were lice (both body lice and head lice) and bed bugs. Children often used humour to cope with this inconvenience and thus immortalized these pests in their drawings, writings, magazines, and diaries $(9,12)$.

Children represented a high percentage of patients. At the time of epidemics, 30 to $55 \%$ of the children were sick. The care of healthy children was a role of the Department of Youth Care, the care of sick children belonged to the Department of Health. The main task of the Jewish self-government of the camp was a decentralized healthcare, and the need for strictly separate residential units with minimal possibilities of contact $(2,6,9)$.

Health units were set up by district. A children's hospital Q217/19 was set up especially for the treatment of scarlet fever in children in the first district (2). Michaela Vidláková (six years old at the time) was treated at this hospital. "I was hospitalized in a small infectious hospital (Q 217), a common one-story house where mainly typhoid but also other infectious diseases were treated, including tuberculosis. We were 3 to 4 in the room, later I was in a larger room for 6 beds. I remember the white-coated beds and the immense kindness and care of nurses and doctors." Marta Kottová remembers the times when epidemics of infectious diseases caused a shortage of beds in the hospitals, they placed two children into one bed according to their diagnoses and condition.

The facility in building Q 710 ran out-patient care and an infirmary for the youth in the third district. The facility in building Q 617 ran out-patient care and an infirmary for children in the fourth district. In the fourth district, there were ambulances and baby booties for children at Q 617. The facilities in buildings L410, L 414, L417 provided out-patient care and infirmaries in the youth homes, homes for infants and toddlers, and the central children's dental ambulance (Q619). Amalgam, silver or cement was used for dental fillings. The children were also hospitalized in children's rooms in the departments of adult hospitals, particularly in infectious wards $(1,6)$.

There were very few medications, and only basic medications (like Aspirin) was available. According to Michaela Vidláková, the main methods of treatment included bed rest, cold compress, diet (brew made of peeled barley or oat flakes, later mashed potatoes). "There was almost no medication. I remember a shortterm administration of sulphonamides, namely Prontosil from Bayer, enema was often applied, diphtheria was treated only by scraping the mucous coating in the throat and then compresses against fever. I recall some children had deep indentations behind ears after trepanation treatment of acute otitis media." Marta Kottová remembers treatment of typhoid fever "Typhoid fever caused either constipation or diarrhoea. One girl called Karla was constipated, and after she had an enema, she did not discharge the water. The nurse had to remove the stool using her fingers to help her. Professor Salus and a nurse called Mariana kept telling us, children, don't move, I'll do everything to you, just don't move." These treatment methods are verified by memoirs of a nurse Hana Muller Bruml, who also mentions sulphonamide Cibazol produced by CIBA, which was very rare and had to be smuggled into Theresienstadt (13).

Hospitals, out-patient departments, and infirmaries had to deal not only with a lack of medication but also with a shortage of instruments. The Order of the day by the Council of the Elders from September 16th 1942, includes a call upon the inmates to provide fever thermometers. The need for thermometers was highlighted by mentioning a fact that only one thermometer was available for 58 patients. However, we can observe the opposite trend in the area of diagnostics, which showed a high activity and usefulness, especially due to sufficient and quality equipment. Laboratories performed analysis of urine, blood, and other body fluids samples. An X-ray machine and an ECG device were also available in Theresienstadt. The children were irradiated very often. The effects of frequent $\mathrm{x}$-rays on health have been proven for many years. This equipment came from the confiscated property of Jewish doctors in occupied Europe and from closed Jewish hospitals or Jewish senior homes $(6,14-16)$.

The daily routine in Theresienstadt hospitals was quite similar to a contemporary hospital. Helga Weissová describes the regime of infectious hospital in the former gym of Sokol gymnastic society: "One doctor and one nurse work the night shift. During the day there are about five to six nurses. Ward rounds were attended by the head doctor, two male doctors, two female doctors, head nurse, and three or four regular nurses. Patients are woken at six; a nurse takes the pulse and the temperature. Ward rounds are done by an assigned physician at nine and by the head doctor at about eleven. In the afternoon, professor Sitting, a neurologist, examined new patients. New patients lie in the foyer, where there are nine beds." (9).

Sick children were attended by doctors, professional sisters, and auxiliary nurses. Some members of the staff had training from the pre-war era. Women without training who were interested 
in the job of a nurse could complete their education in courses organized in the ghetto (14).

To work as a nurse in the ghetto was in a high demand. The women who did this work found great satisfaction and motivation to survive. Most women caring for sick children were able to overcome the ubiquitous fear for their own life and for their children. Ilse Weberová was a famous Theresienstadt nurse in the children's infirmary. To comfort and brace up her fellow prisoners, she composed poems and songs that spread through the ghetto. In October 1944 she volunteered to join the transport of the children from the infirmary to Auschwitz, into which her son was assigned. Immediately on arrival at the extermination camp, she was murdered with all the children in the gas chamber (17-19).

Michaela Vidláková recalls a few doctors, namely a kind doctor Bruno Mandl from Brno (transported to Theresienstadt by Transport AAm on 4th July, 1942, transported to Auschwitz by Transport Em on 1st October 1944 where he died) and a head doctor MUDr. Hans Schaffa. She also remembers several nurses, particularly Hana Schiffová (her mother's cousin) and Alice Friedová (11).

Strict evidence was required for the treatment. Children had to present a so-called "small health card". Sick children received the so-called food supplement, which meant two or three tablespoons of oatmeal administered by a home social worker $(6,9,13)$.

It was generally allowed to visit sick children in hospitals during the visiting hours, except for the infectious wards where visits were forbidden. As Michaela Vidláková remembers: "Visits were not permitted in this department; we could see our parents through the window glass only. My letters had to be ironed by a hot iron before they left the infected environment."

All children had to comply with a very strict regime regarding their health and disease prevention. Children were encouraged to bodily movement, a frequent and thorough hygiene of hands, cleanliness of the body and their general environment, airing of mattresses, and cleaning chores. An important preventive measure in children was delousing. The situation improved by using hot air. However, hot air could not be used to delouse straw mattresses, blankets and clothing because of the risk of fire. Significant improvement was reached by utilization of the cyanide Cyclone B. Also, burning sulphur was used as a pest control technique in rooms $(9,13,18)$.

Apart from lice, flies, bed bugs, fleas, and rats had to be killed $(1,12)$. The need for preventive measures is illustrated by the number of calls in the Orders of the day by the Council of the
Elders (Table 4). For illustrative purposes, selected orders are presented below.

Order of the day no. 263 (9th December, 1942). "Call for cleanliness. Ghetto residents are exposed to various health hazards and must also be protected. The greatest danger is typhoid and lice. Much can be achieved by following a few simple hygienic rules. Typhoid infection is almost always spread through dirty hands, so it is necessary to have clean hands with short cut nails, to wash your hands before eating and after the stool. To fight lice, you need to keep your body, clothing, and housing clean. Every day rooms have to be aired several times, and you must not sleep in your daily clothes. Indolence must not stand in the way of keeping hygiene regulations. Also spitting and littering in the streets, yards and corridors is strictly forbidden." (14).

Order of the day no. 347 (30th July 1943). "A thorough intervention minimized infestation with lice in the ghetto. However, preventive controls will continue. These are mandatory; those who do not subject to them will be punished." (14).

Other anti-epidemic measures included vaccination, especially against diphtheria, scarlet fever, typhoid fever, and smallpox. It is possible to suggest, based on historical sources, that serumprophylactic was meant to be vaccination. For instance, in case of scarlet fever it used to be the application of the serum to the recovering patient or the serum of antiscarlet native intramuscularly $(3,6,14,20)$.

Below you find selected orders that illustrate the issue.

Report by the Jewish self-government 17 (3rd June, 1944). "Mandatory vaccination against scarlet fever for persons aged 1.5 years to 40 years, three times at fourteen-day intervals, then repeat after two years." (14).

Report by the Jewish self-government 17 (3rd June, 1944). "Mandatory vaccination against diphtheria for persons aged 3 to 18 years, two times at fourteen-day intervals, then repeat after a year." (14).

Report by the Jewish self-government 17 (3rd June, 1944). "Mandatory vaccination against typhoid fever for persons aged 3 to 65 years, three times at seven-day intervals, repeat after six months." (14).

\section{DISCUSSION}

One of the Nazi plans to exterminate the Jewish people was aimed at children as an embryo of future generations. Not only

Table 4. Anti-epidemic measures - number of calls in the Orders of the day by the Council of the Elders (14)

\begin{tabular}{|c|c|c|c|c|c|c|c|c|c|c|c|c|}
\hline Year & 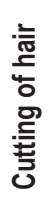 & 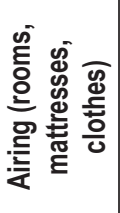 & 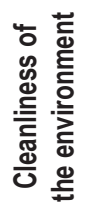 & 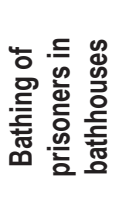 & 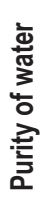 & 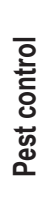 & 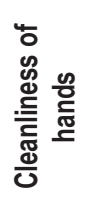 & 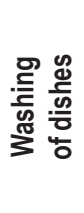 & 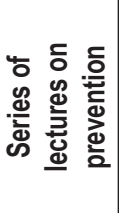 & 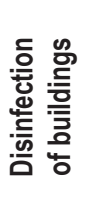 & 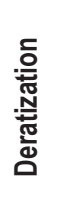 & 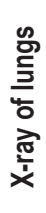 \\
\hline 1941 & 2 & 1 & 1 & - & - & - & - & - & - & - & - & - \\
\hline 1942 & 2 & 1 & 11 & 2 & 1 & 1 & 5 & - & - & - & - & - \\
\hline 1943 & - & 3 & 10 & - & - & - & 1 & 1 & 1 & 1 & 2 & \\
\hline 1944 & - & - & 2 & 3 & 1 & - & 3 & - & - & - & 1 & 1 \\
\hline Total & 4 & 4 & 24 & 5 & 2 & 1 & 9 & 1 & 1 & 1 & 3 & 1 \\
\hline
\end{tabular}


were the children among the first to be sent to gas chambers of the concentration camps, the Nazis also tried to prevent childbirth, and strict records were kept regarding this issue. In spite of that, Jewish children were born in Theresienstadt and other internment facilities. From the 150 children born in Theresienstadt, 31 died in the ghetto, 102 in the gas chambers of the concentration camps and only 17 were liberated in the ghetto at the end of the war. When researching care for children in Theresienstadt, one should keep in mind that this camp was initially established as a showcase to create the illusion Hitler is kind to Jews. This should explain why care of children was on a relatively high level compared to other internment facilities $(1,20)$.

The Jewish community is historically characterized by cohesion and social sympathy for the weaker groups, which was also evident in Theresienstadt in the care of sick and weak prisoners, especially children. It can be said that, to ensure the survival of the next generation, this care was at the expense of older prisoners. From these characteristics of the Jewish community we can assume that a similar situation regarding childcare was similar in other European Jewish ghettos and concentration camps. By studying life in selected Jewish ghettos in Eastern Europe, this assumption can be verified.

For example, the Lithuanian Jewish ghetto in Vilnius had a very sophisticated system of health care for its inmates. The incidence of infectious diseases was lower than in Polish ghettos. As in Theresienstadt there was only a low number of malnourished or poor people. Even in the Lithuanian Jewish ghetto, there were many well-educated doctors and nurses, who had often studied abroad. The Department of Preventive Medicine and Hygiene was responsible for the prevention and treatment of infectious diseases. In the field of prevention of children's diseases, we can see the following differences in Vilnius. At the time of the disease, the heads of children were shaved. This measure stopped being applied before the ghetto was wiped out, so that children who were secretly sent to non-Jewish Lithuanian families could not be identified. In this ghetto, there was a very curious system of young hygienic assistants. These were seven- to eight-year-old boys who checked the cleanliness of houses and flats, and also recorded the numbers of people in the spa (21).

The incidence of infectious diseases in prison children in the Warsaw ghetto was comparable to Theresienstadt in relation to variables (e.g. number of prisoners in the ghetto, the residential area). There were many major differences between these ghettos. Several epidemics with lethal consequences were recorded in Warsaw among children. There were several children's hospitals in the Warsaw ghetto and a school that educated not only nurses but also Jewish doctors (22).

Contrary to the above-mentioned, the situation in the Auschwitz concentration camp was incomparable (23).

\section{CONCLUSION}

This paper presents the system of care for sick children and the youth in the Theresienstadt ghetto. Children's morbidity did not reflect only poor hygienic and living conditions in the camp, but also the state of the medical science of its time. The Jewish selfgovernment of Theresienstadt made great effort to help children, who were perceived as a guarantee of Jewish nation's survival and as a foundation for future generations. Care for both healthy and sick children was carried out selflessly by doctors, nurses and wardens. Their commendable work must be commemorated not only because they took care of vulnerable children in situation where their own lives were often threatened, but also because they became life-long role models for children who survived.

\section{Conflicts of Interests}

None declared

\section{REFERENCES}

1. Lagus K, Polák K. The town behind bars. Prague: Naše vojsko; 1964. (In Czech.)

2. Adler HG. Theresienstadt 1941-1945: the face of a coerced community: I. history. Brno: Barrister \& Principal; 2006. (In Czech.)

3. Kulišová T. Small fortress Theresienstadt. Prague: Naše vojsko; 1964. (In Czech.)

4. Diamant J. Notes about the psychology of life in the concentration camp in Terezín. In: Terezín letters: proceedings of the Terezín Memorial. Prague: Oswald; 1995. p. 43-53. (In Czech.)

5. Beck AT. Cognitive therapy and emotional disorders. Prague: Portál; 2005. (In Czech.)

6. Adler HG. Theresienstadt 1941-1945: the face of a coerced community: II. sociology. Brno: Barrister \& Principal; 2006. (In Czech.)

7. Prochnik R. The Jews in Terezín: statistical compilation. Prague: Jewish Museum in Prague; 1945. (In Czech.)

8. Lederer Z. Ghetto Theresienstadt. New York: Fertig; 1953.

9. Brenner-Wonschick H. The Girls of room 28: friendship, hope, and survival in Theresienstadt. Prague: Barrister \& Principal; 2007. (In Czech.)

10. Löwith K. Cases of Death from Tuberculosis in Terezín [Internet]. Prague: Jewish Museum in Prague; 1944 [cited 2020 Jan 13]. Available from: http://collections.jewishmuseum.cz/index.php/Detail/Object/Show/ object_id/137063.

11. Database of victims [Internet]. Prague: Jewish Museum in Prague. c2013-2020 [cited 2020 Jan 13]. Available from: http://www.holocaust. cz/databaze-obeti.

12. Pick J, Polák R, Pacovský J. Theresienstadt in the eyes of a hygienist: the report from the concentration camp in Terezín on the fight against insects and typhus. Prague: Lékařské knikupectví a nakladatelství; 1948. (In Czech.)

13. Ritvo RA, Plotkin DM. Sisters in Sorrow. Tamu (TX): A\&M University Press; 2000.

14. Orders of the day by the Council of the Elders and Reports of the Jewish self-government of Theresienstadt 1941-1945. Hyndráková A, editor. Prague: Sefer; 2003. (In German.)

15. Akkurt I, El-Khayatt AM. The effect of barite proportion on neutron and gamma-ray shielding. Ann Nucl Energy. 2013;51:5-9.

16. Pelnáŕ J. Pathology and therapy internal diseases. Prague: Bursík \& Kohout; 1940. (In Czech.)

17. Auředníčková A. Tree years in Theresienstadt. Prague: Alois Hynek; 1945. (In Czech.)

18. Ondřichová L. Story of Fredy Hirsh. Prague: Sefer; 2001. (In Czech.)

19. Weber I. When our suffering stops: letters (1933-1944) and poems from Theresienstadt. Migdal U, editor. Prague: Academia; 2012. (In Czech.)

20. Hájková V. Terezin's youngest prisoners. In: Terezín letters: proceedings of the Terezín Memorial. Prague: Oswald; 1998. p. 58-70. (In Czech.)

21. Longacre M, Beinfeld S, Hildebrandt S, Glantz L, Grodin MA. Public health in the Vilna Ghetto as a form of Jewish resistance. Am J Public Health. 2015;105(2):293-301.

22. Weisz GM, Grzybowski A, Albury WR. The Fate of the Warsaw Ghetto Medical Faculty. Isr Med Assoc J. 2012;14(4):209-13.

23. Lang HJ. Women in barracks 10: medical experiments in Auschwitz. Prague: Euromedia Group - Ikar; 2014. (In Czech.)

Received October 3, 2018 Accepted in revised form April 21, 2020 